\title{
Originals
}

\section{Lipolysis and Cyclic AMP Levels in Epididymal Adipose Tissue of Obese-Hyperglycaemic Mice}

\author{
J.P. Dehaye, J. Winand, and J. Christophe \\ Department of Biochemistry and Nutrition, Free University of Brussels Medical School, Brussels, Belgium
}

Summary. Glycerol release from epididymal fat fragments of young adult (3-month old) ob/ob mice was three times lower than normal, on a tissue weight basis. Dose-response curves in response to isoproterenol and ACTH- $(1-24)^{1}$ indicated that the capacity of the lipolytic process was reduced. However, the sensitivity to both hormones was normal, i.e. greater for ACTH than for isoproterenol. The burst of cyclic AMP observed at 7 minutes was affected even more than the lipolytic capacity in adipose tissue from obese mice. This was already observed in 1-month old animals, i.e. at a time when total body weight was still normal. It is concluded that the adenylate cyclase system is defective in adipose tissue of ob/ob mice. Besides, glucagon, vasoactive intestinal polypeptide, and secretin failed to stimulate glycerol release and cyclic AMP accumulation in both ob/ob, ob+/ob+, and HA-ICR mice, suggesting that mouse adipose tissue does not possess receptors for this group of hormones.

Key words: Obese-hyperglycaemic mice, adipose tissue, lipolysis, glycerol, cyclic AMP, adenylate cyclase, isoproterenol, ACTH-(1-24), glucagon, vasoactive intestinal polypeptide, secretin.

The "second messenger" concept has helped to demonstrate the key-role of cyclic AMP in mediating the action of lipolytic hormones $[1,2]$. These hormones bind to specific receptors on the plasma membrane of fat cells and the resulting adenylate cyclase activation provokes an accelerated conver-

1 List of abbreviatons cyclic AMP $=$ adenosine $3^{\prime}, 5^{\prime}$-cyclic monophosphate, VIP = vasoactive intestinal polypeptide; ACTH = corticotrophin-(1-24)-tetracosapeptide sion of ATP to cyclic AMP. The following dissociation of cyclic AMP dependent protein kinase(s) allows, in turn, the phosphorylation of inactive hormone-sensitive triglyceride lipase to give the active form of this enzyme $[3,4,5]$.

Obesity associated with insensitivity of adipose tissue to lipolytic hormones has been described in New Zealand obese mice $[6,7]$, ob/ob mice [8], $\mathrm{db} / \mathrm{db}$ mice [9], gold-thioglucose obese mice [10], hypothyroid rats [11], and in man [12]. This defect has been correlated in New Zealand obese mice with a lack of cyclic AMP accumulation following hormonal activation [6]. The adipose tissue of the obese-hyperglycaemic mouse has been thoroughly investigated. A decrease in the number of insulin receptors per $\mathrm{mg}$ of plasma membrane protein of adipocytes has been documented [13]. However, reports on the action of lipolytic hormones are conflicting. Stimulation of lipolysis by lipolytic hormones or various agents in the adipose tissue of obese mice has been described as being reduced [8], normal [14] or augmented [15, 16]. Moreover, doseresponse curves documenting increases in cyclic AMP concentration and lipolysis have not as yet been correlated. Our purpose was to examine these two aspects, in order to localize more precisely any defect which might contribute to the Bar-Harbor syndrome.

\section{Materials and Methods}

Male C57 BL/6J obese-hyperglycaemic homozygous (ob/ob) mice and lean homozygous (ob+/ $\mathrm{ob}+)$ mice were raised in the laboratory. This colony was started with animals purchased from the Jackson Memorial Laboratories (Bar Harbor, Maine, U.S.A.) and fed, ad libitum, on a standard 
laboratory chow (U.A.R., Villemoisson, France). Except in one experiment, all the mice used were 3 months old. Obese animals weighed $39.8 \pm 0.8 \mathrm{~g}$ (mean value \pm SEM, $\mathrm{n}=36$ ), in contrast to the lean controls, weighing $26.6 \pm 0.7 \mathrm{~g}(\mathrm{n}=36)$. Blood glucose and insulin levels were, respectively, $150 \pm 10 \mathrm{mg} / 100 \mathrm{ml}$ and $250 \pm 15 \mu \mathrm{U} / \mathrm{ml}$ in ob/ob mice and $92 \pm 6 \mathrm{mg} / 100 \mathrm{ml}$ and $19 \pm 3 \mu \mathrm{U} / \mathrm{ml}$ in lean mice. The epididymal adipose tissue wet weight was $2.22 \pm 0.40 \mathrm{~g}$ in ob/ob mice in contrast to 0.42 $\pm 0.10 \mathrm{~g}$ in control animals. In one extra experiment, ob/ob mice were only 4 weeks of age and their body weight $(19.9 \pm 0.9 \mathrm{~g} ; \mathrm{n}=7)$ did not differ from that of the controls $(18.8 \pm 0.9 \mathrm{~g}$; $\mathrm{n}=7$ ). However, the weight of their epididymal adipose tissue was already greater: $0.43 \pm 0.06 \mathrm{~g}$ vs $0.11 \pm 0.03 \mathrm{~g}$.

Theophylline and isoproterenol were obtained from Sigma Chemical Co. (St. Louis, Mo., U.S.A.), bovine serum albumin from Poviet (Amsterdam, The Netherlands), glycerol-3-phosphate dehydrogenase and glycerol kinase from Boehringer (Mannheim, West-Germany). ACTH (synthetic corticotrophin (1-24)-tetracosapeptide) was a gift from Ciba-Geigy Ltd (Basel, Switzerland). Pure crystalline porcine glucagon was from Eli Lilly and Co. (Indianapolis, Ind., U.S.A.). Highly purified natural porcine vasoactive intestinal peptide (VIP) and natural porcine secretin were given by Dr. V. Mutt from the GIH Research Unit of the Karolinska Institutet (Stockholm, Sweden). All the other products were of the highest analytical grade available.

\section{Incubation Conditions for Cyclic AMP and Glycerol Determinations}

In 'each experiment, six lean and six obese mice were killed by cervical dislocation. The two epididymal fat pads of each animal provided twelve $45-55 \mathrm{mg}$ pieces. These fragments were randomly distributed in twelve flasks containing $2 \mathrm{ml}$ KrebsRinger bicarbonate buffer supplemented with $4 \%$ bovine serum albumin. Theophylline $(1 \mathrm{mmol} / \mathrm{l})$ was also present for cyclic AMP assays, but was omitted when lipolysis was measured. The $\mathrm{pH}$ was maintained at 7.4 by a continuous flow of $95 \% \mathrm{O}_{2}+5 \%$ $\mathrm{CO}_{2}$. After a preincubation of 30 minutes at $37^{\circ} \mathrm{C}$, in order to remove endogenous hormones, the fragments were transferred to identical vials containing the same incubation medium with or without a lipolytic agent.

For cyclic AMP determination the incubations were stopped by removing and freezing the fragments at $-70^{\circ} \mathrm{C}$ in $2 \mathrm{ml} 10 \%$ trichloroacetic acid (TCA). The frozen samples were homogenized by ultrasonication. The homogenates were centrifuged for 15 minutes at $1100 \mathrm{~g}$ and both the floating fat cake and the pellet were discarded. The internatant was acidified with $0.1 \mathrm{ml} \mathrm{mol} / 1 \mathrm{HCl}$ and TCA was eliminated by 5 succesive extractions with diethyl ether. The extract was freeze-dried, then dissolved in water and assayed in triplicate for cyclic AMP according to Gilman et al. $[17,18]$.

The net release of glycerol was used as an index of lipolysis, owing to the weak activity of glycerol kinase in adipose tissue [19], even in the case of obese mice, where a maximum of $20 \%$ of the liberated glycerol might theoretically be phosphorylated [20]. On the basis of preliminary time studies showing linear rates of glycerol release in the absence of theophylline, it was found convenient to determine the glycerol accumulated in the medium at the end of a 90 minute incubation period in the presence of the hormone, after the 30 minute preincubation without hormone. The tissue fragments were discarded and medium albumin precipitated with $1 \mathrm{ml}$ of $15 \%(w / v)$ perchloric acid. After centrifugation, the supernatant was neutralized with $\mathrm{KHCO}_{3}$. After a second centrifugation, glycerol was measured enzymatically [21].

\section{Results}

\section{A. Effects of Isoproterenol}

In normal mice, the average level of cyclic AMP in adipose tissue was $15 \pm 3$ pmoles $/ 100 \mathrm{mg}$ fresh tissue in the presence of $1 \mathrm{mmol} / 1$ theophylline (Fig. 1), i.e. three times higher than in the absence of the methylxanthine (Table 1). Isoproterenol, when used alone at a maximal $2.5 .10^{-6} \mathrm{~mol} / 1 \mathrm{con}$ centration, was no more efficient (Table 1). However, isoproterenol and theophylline, when used in combination, doubled cyclic AMP levels within one minute and a peak value of $208 \pm$ 20 pmoles $/ 100 \mathrm{mg}$ fresh tissue was reached after 7 to 10 minutes. This concentration then fell and returned to its initial level after 60 minutes, in spite of the continued presence of isoproterenol and theophylline (Fig. 1).

In obese mice, with only $1 \mathrm{mmol} / 1$ theophylline or $2.5 .10^{-6} \mathrm{~mol} / \mathrm{l}$ isoproterenol present in the incubation medium, the level of cyclic AMP was, respectively, $8 \pm 2$ pmoles and $4 \pm 1$ pmoles $/ 100 \mathrm{mg}$ fresh tissue, as compared to basal levels of $2 \pm$ 1 pmoles $/ 100 \mathrm{mg}$ fresh tissue (Table 1 ). After addition of isoproterenol and theophylline together, cyclic AMP increased ( $30 \pm 4$ pmoles) after 7 minutes to four times the value obtained with theo- 


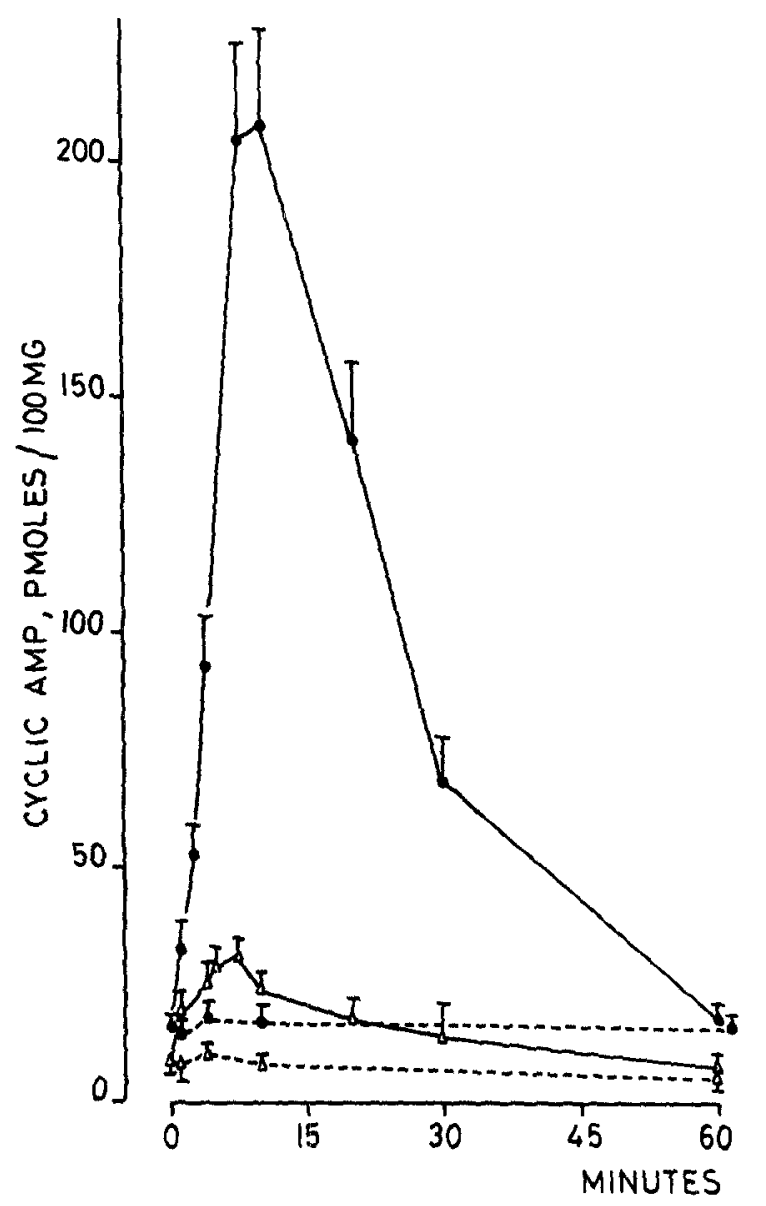

Fig. 1. Effects of $2 \cdot 5 \cdot 10^{-6} \mathrm{~mol} / 1$ isoproterenol on the time course of changes in cyclic AMP levels in epididymal adipose tissue of 3 month old normal $(\bullet)$ and obese-hyperglycaemic mice $(\Delta)$. Adipose tissue fragments were incubated with $1 \mathrm{mmol} / 1$ theophylline and with $(-)$ or without $(--)$ isoproterenol as indicated under Materials and Methods. Values are means \pm SEM of 4 experiments

phylline only. It then progressively returned to control values within 60 minutes.

In one experiment, younger ob/ob animals aged 4 weeks were used to see whether the impairment in cyclic AMP accumulation preceded the increase in body weight (Fig. 2). In lean control mice, isoproterenol increased cyclic AMP levels from 40 \pm 5 to $715 \pm 85$ pmoles $/ 100 \mathrm{mg}$ fresh tissue within 5 minutes. In young obese mice, whose body weight did not yet differ from that of their lean controls, these values were, respectively, $10 \pm 3$ and 45 \pm 7 pmoles. In both types of mice a decrease in cyclic AMP levels was noted with time.

A dose-response curve for cyclic AMP accumulation following hormonal stimulation was performed at 7 minutes in 3 month old mice. As can be seen in Figure $3 \mathrm{~A}$, minimal, half-maximal and maximal effects were obtained, respectively, with $10^{-7} \mathrm{~mol} / 1, \quad 3.10^{-7} \mathrm{~mol} / 1$ and $3.10^{-6} \mathrm{~mol} / 1$ iso-

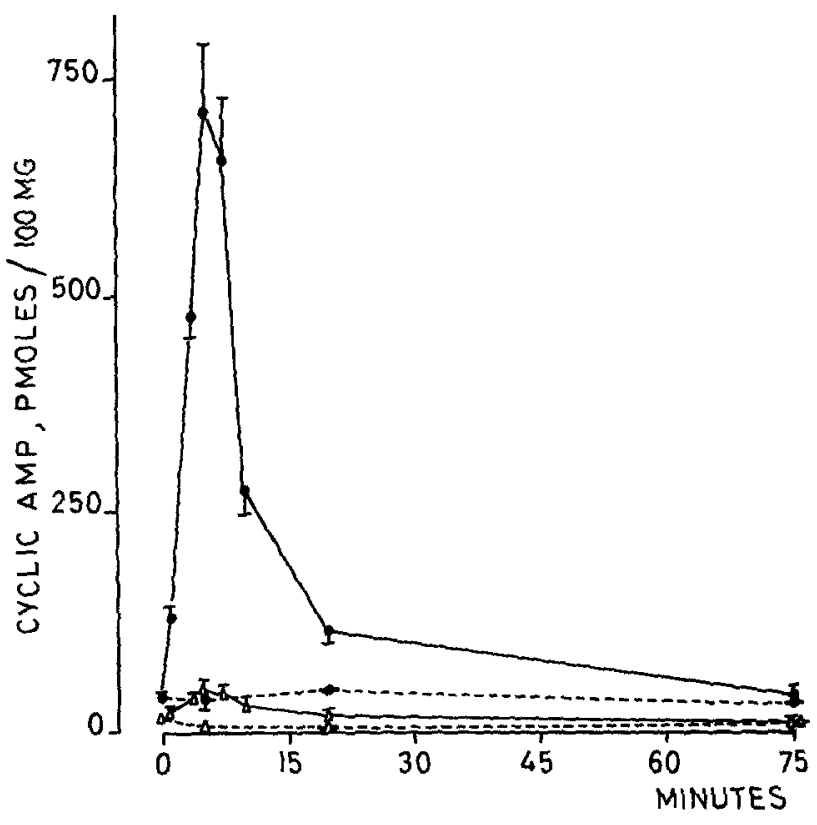

Fig. 2. Effect of $2.5 .10^{-6} \mathrm{~mol} / 1$ isoproterenol on the time course of changes in cyclic AMP levels in epididymal adipose tissue of one month old normal $(\bullet)$ and obese-hyperglycaemic $(\Delta)$ mice. Adipose tissue fragments were incubated with isoproterenol as indicated in Figure 1. Values are means \pm SEM of 3 experiments

Table 1. Effects of theophylline and isoproterenol only, and of isoproterenol, ACTH-(1-24), glucagon, vasoactive intestinal polypeptide (VIP), and secretin used in combination with theophylline, on cyclic AMP levels in epididymal adipose tissue from lean and obese-hyperglycaemic mice. Cyclic AMP levels were determined after 7 minutes incubations. Results are expressed as pmoles cyclic AMP/100 mg fresh tissue and are means of four experiments $\pm \mathrm{SEM}$

\begin{tabular}{|c|c|c|}
\hline Additions & Lean mice & $\begin{array}{l}\text { Obese- } \\
\text { hyperglycaemic mice }\end{array}$ \\
\hline Control & $5 \pm 1$ & $2 \pm 1$ \\
\hline Theophylline $10^{-3} \mathrm{~mol} / 1$ & $15 \pm 3$ & $8 \pm 2$ \\
\hline Isoproterenol $25.10^{-6} \mathrm{~mol} / 1$ & $13 \pm 3$ & $4 \pm 1$ \\
\hline $\begin{array}{l}\text { Isoproterenol } 2.5 .10^{-6} \mathrm{~mol} / 1 \\
\text { Theophylline } 10^{-3} \mathrm{~mol} / 1\end{array}$ & $208 \pm 20$ & $30 \pm 4$ \\
\hline $\begin{array}{l}\text { ACTH }(1-24) 10^{-5} \mathrm{~mol} / 1 \\
\text { Theophylline } 10^{-3} \mathrm{~mol} / 1\end{array}$ & $249 \pm 30$ & $9 \pm 2$ \\
\hline $\begin{array}{l}\text { Glucagon } 10^{-6} \mathrm{~mol} / 1 \\
\text { Theophylline } 10^{-3} \mathrm{~mol} / 1\end{array}$ & $14 \pm 3$ & $7 \pm 1$ \\
\hline $\begin{array}{l}\text { VIP } 10^{-6} \mathrm{~mol} / 1 \\
\text { Theophylline } 10^{-3} \mathrm{~mol} / 1\end{array}$ & $13 \pm 3$ & $6 \pm 1$ \\
\hline $\begin{array}{l}\text { Secretin } 10^{-6} \mathrm{~mol} / 1 \\
\text { Theophylline } 10^{-3} \mathrm{~mol} / 1\end{array}$ & $13 \pm 3$ & $8 \pm 2$ \\
\hline
\end{tabular}



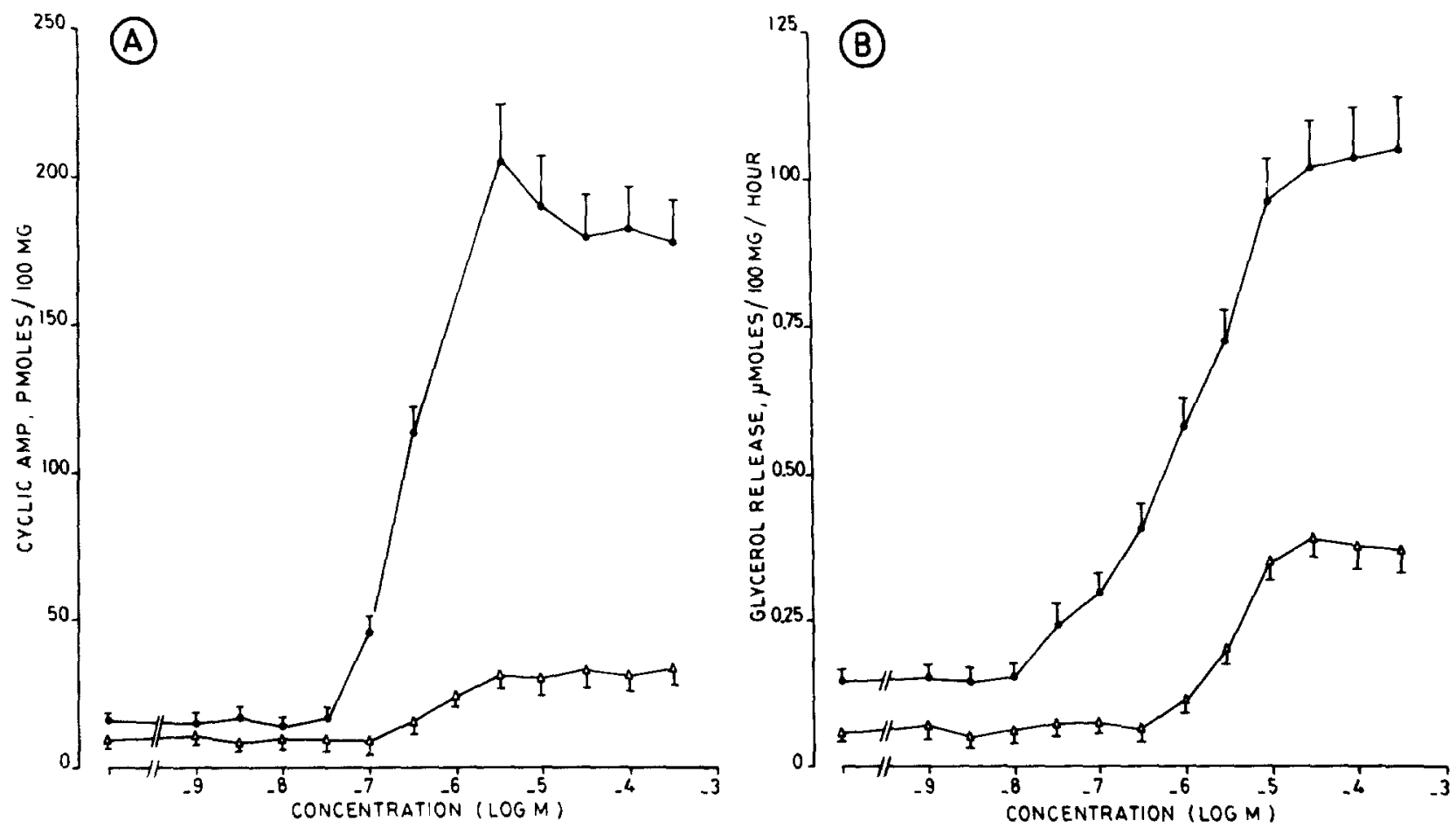

Fig. 3. Dose-response curves of isoproterenol on cyclic AMP levels (3 A) and on glycerol release (3 B) by epididymal adipose tissue of 3 month old normal $(\bullet-)$ ) and obese-hyperglycaemic $(\triangle-\Delta)$ mice. Cyclic AMP levels were assayed after 7 min incubations in the presence of $1 \mathrm{mmol} / 1$ theophylline. Medium glycerol was assayed after $90 \mathrm{~min}$ incubations in the absence of theophylline. Values are means \pm SEM of 4 experiments

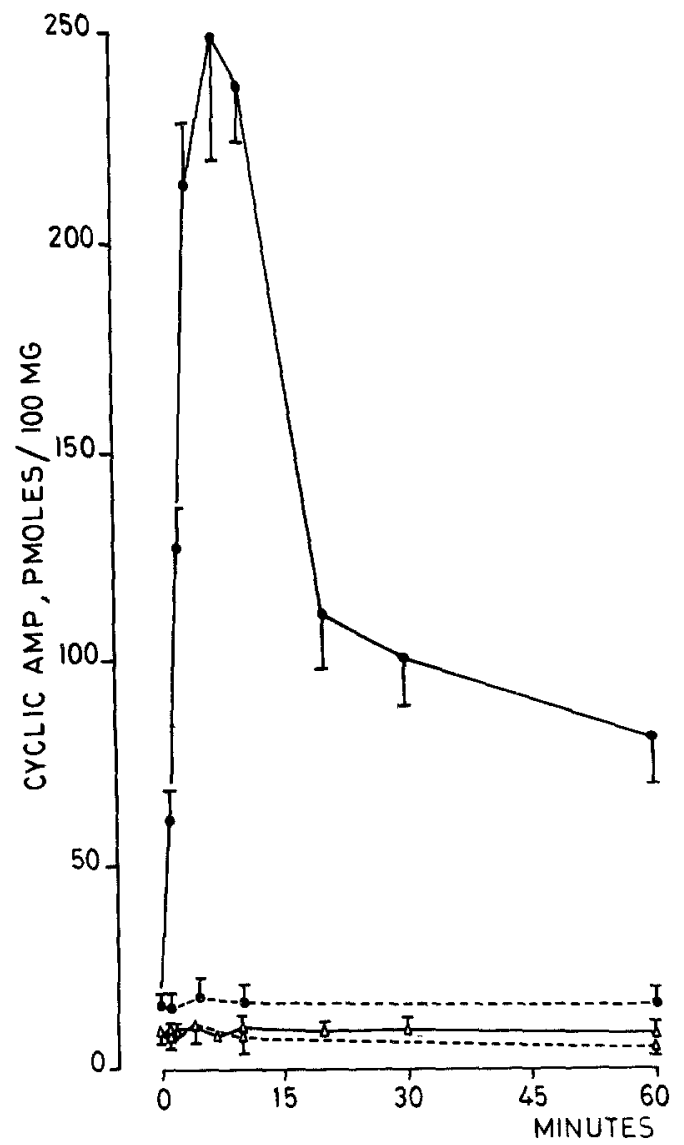

proterenol in normal mice, and $10^{-7} \mathrm{~mol} / \mathrm{l}$, $5.10^{-7} \mathrm{~mol} / 1$ and $3.10^{-6} \mathrm{~mol} / \mathrm{l}$ isoproterenol in obese animals. Supra-maximal concentrations appeared to be somewhat less efficient in normal mice, but this difference was not significant.

In lean mice, the basal release of glycerol observed in the absence of theophylline was $0.14 \pm$ $0.02 \mu$ moles glycerol $/ 100 \mathrm{mg}$ fresh tissue/hour. In presence of $3.10^{-4} \mathrm{~mol} / 1$ isoproterenol, the tissue released 7 times more glycerol (1.04 \pm $0.09 \mu$ moles $/ 100 \mathrm{mg}$ fresh tissue/hour). Half-maximal stimulation occurred at $10^{-6} \mathrm{~mol} / \mathrm{l}$ concentration (Fig. 3B). Basal lipolysis in adipose tissue from $\mathrm{ob} / \mathrm{ob}$ mice was only $0.05 \pm 0.01 \mu$ moles glycerol/100 mg fresh tissue/hour (Fig. 3B). Lipolysis was activated when concentrations of isoproterenol were higher than $3 \cdot 10^{-6} \mathrm{~mol} / \mathrm{l}$. At $3.10^{-5} \mathrm{~mol} / \mathrm{l}$ isoproterenol, the tissue released 0.38 $\pm 0.03 \mu$ moles glycerol $/ 100 \mathrm{mg}$ fresh tissue/hour. Higher concentrations did not alter this response.

Fig. 4. Effect of $10^{-5} \mathrm{~mol} / \mathrm{l}$ ACTH (corticotrophin(1-24)) on the time course of cyclic AMP levels in epididymal adipose t1ssue of 3 month old normal (•) and obese-hyperglycaemic $(\Delta)$ mice. Incubation conditions in the presence of $1 \mathrm{mmol} / 1$ theophylline and with (-) or without (- - ) ACTH were the same as in Figure 1. Values are means \pm SEM of 4 experiments 

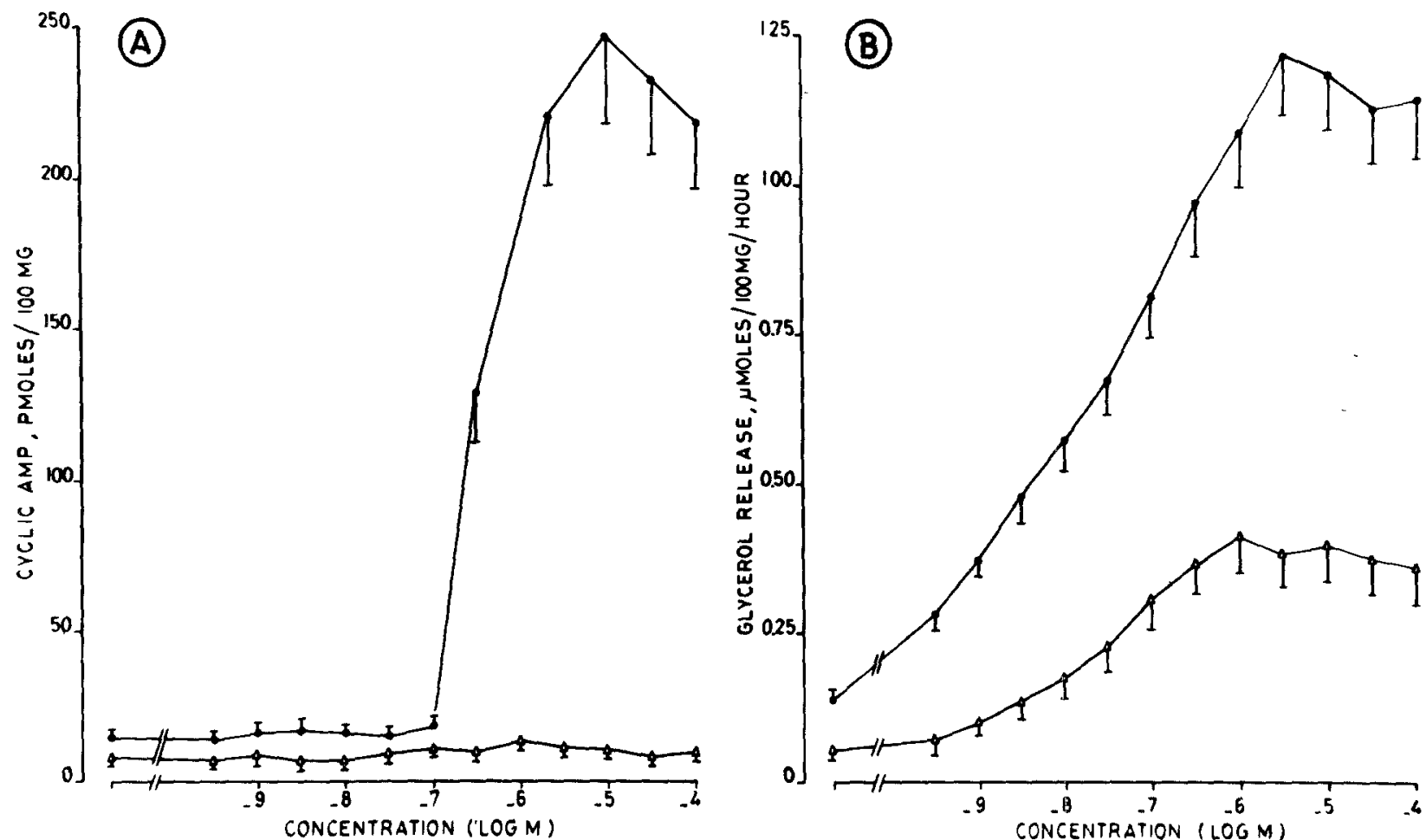

Fig. 5. Dose-response curves of ACTH on cyclic AMP levels (5A) and on glycerol release (5B) by epididymal adipose tissue of 3 month old normal $(\bullet)$ and obese-hyperglycaemic $(\triangle-\Delta)$ mice. Cyclic AMP levels were assayed after 7 min incubations in the presence of $1 \mathrm{mmol} / 1$ theophylline. Medium glycerol was assayed after $90 \mathrm{~min}$ incubations in the absence of theophylline. Values are means \pm SEM of 4 experiments

\section{B. Effects of ACTH}

In normal mice, the stimulation of cyclic AMP levels by $10^{-5} \mathrm{~mol} / 1 \mathrm{ACTH}$ was rapid in the presence of $10^{-3} \mathrm{~mol} / 1$ theophylline. After only one minute of incubation, cyclic AMP levels had risen from 15 \pm 3 to $61 \pm 7$ pmoles $/ 100 \mathrm{mg}$ fresh tissue, and, after 7 minutes, a 25 -fold increase in cyclic AMP concentration was observed (Fig. 4). This peak value ( $249 \pm 30$ pmoles $/ 100 \mathrm{mg}$ ) was followed by a progressive fall and, after 60 minutes, control values were almost overtaken. Concentrations of ACTH higher than $10^{-7} \mathrm{~mol} / \mathrm{l}$ were able to stimulate the accumulation of cyclic AMP (Fig. 5 A). Half-maximal stimulation was obtained with $3.10^{-7} \mathrm{~mol} / 1 \mathrm{ACTH}$ and the maximal stimulation at about $3.10^{-6} \mathrm{~mol} / 1$. At concentrations above $10^{-5} \mathrm{~mol} / 1$, cyclic AMP accumulation decreased moderately but not significantly.

By contrast, ACTH could not increase the concentration of cyclic AMP at any time in adipose tissue from obese mice (Fig. 4). The inability of this hormone to influence cyclic AMP levels in obese mice was confirmed by dose-response experiments. Even concentrations as high as $10^{-4} \mathrm{~mol} / 1$ could not affect cyclic AMP levels significantly (Fig. $5 \mathrm{~A}$ ).

In order to activate lipolysis, low concentrations of ACTH were sufficient in both mice. In lean ani- mals, a $3.10^{-10} \mathrm{~mol} / 1$ concentration already increased 3 times the release of glycerol and a $3.10^{-8} \mathrm{~mol} / 1$ concentration gave half-maximal effects. However, to obtain the maximal release, a $3.10^{-6} \mathrm{~mol} / \mathrm{l}$ concentration was necessary (Fig. 5B). ACTH also elicited a dose-related increase in glycerol release in obese mice. Half-maximal effects were obtained with $3.10^{-8} \mathrm{~mol} / 1 \mathrm{ACTH}$, and $10^{-6} \mathrm{~mol} / 1$ ACTH produced maximal liberation: $0.41 \pm 0.06 \mu$ moles glycerol $/ 100 \mathrm{mg}$ fresh tissue/ hour (Fig. 5B).

\section{Effects of Glucagon, Secretin and VIP}

The effects of glucagon, VIP, and secretin were tested on adipose tissue from both kinds of mice (Table 1). At concentrations as high as $10^{-6} \mathrm{~mol} / \mathrm{l}$, the three hormones were still unable to stimulate the accumulation of cyclic AMP after 7 minutes (in the presence of $10^{-3} \mathrm{~mol} / \mathrm{l}$ theophylline) and the release of glycerol after 90 minutes (in the absence of the methylxanthine). A time-study performed with $10^{-6} \mathrm{~mol} / 1$ glucagon confirmed that cyclic AMP levels were not modified, either in normal or obese mice, during the whole course of a 90 -minute incubation in the presence of $10^{-3} \mathrm{~mol} / 1$ theophylline (data not shown). 
Table 2. In vitro sensitivity and capacity of the lipolytic process and of cyclic AMP levels to respond to isoproterenol and ACTH-(1-24) in the epididymal adipose tissue of obese-hyperglycaemic mice and their lean controls

\begin{tabular}{|c|c|c|c|c|c|}
\hline \multirow[t]{2}{*}{ Hormone } & \multirow[t]{2}{*}{ Parameter } & \multicolumn{2}{|l|}{ Lean mice } & \multicolumn{2}{|c|}{ Obese-hyperglycaemic mice } \\
\hline & & Lipolysis & $\begin{array}{l}\text { Burst of } \\
\text { cyclic AMP }\end{array}$ & Lipolysis & $\begin{array}{l}\text { Burst of } \\
\text { cyclic AMP }\end{array}$ \\
\hline \multirow[t]{6}{*}{ Isoproterenol } & $\begin{array}{l}\text { Sensitivity } \\
\text { (in mol/l) }\end{array}$ & & & & \\
\hline & A. minimal & $3.10^{-8}$ & $10^{-7}$ & $10^{-6}$ & $10^{-7}$ \\
\hline & B. half-maximal & $10^{-6}$ & $3.10^{-7}$ & $5.10^{-6}$ & $5.10^{-7}$ \\
\hline & C. maximal & $3.10^{-5}$ & $3.10^{-6}$ & $3.10^{-5}$ & $3.10^{-6}$ \\
\hline & Capacity $^{b}$ & $0.90^{\mathrm{b}}$ & $190^{\mathrm{b}}$ & $0.33^{\mathrm{b}}$ & $22^{b}$ \\
\hline & & umoles & pmoles & umoles & pmoles \\
\hline \multirow[t]{6}{*}{ ACTH-(1-24) } & $\begin{array}{l}\text { Sensitivity } \\
\text { (in } \mathrm{mol} / \mathrm{l} \text { ) }\end{array}$ & & & & \\
\hline & A. Minimal & $3.10^{-10}$ & $10^{-7}$ & $10^{-9}$ & undetectable \\
\hline & B. half-maximal & $3.10^{-8}$ & $3.10^{-7}$ & $3.10^{-8}$ & undetectable \\
\hline & C. maximal & $3.10^{-6}$ & $3.10^{-6}$ & $10^{-6}$ & undetectable \\
\hline & Capacity & $1.08^{\mathrm{b}}$ & $234^{\mathrm{b}}$ & $0.36^{\mathrm{b}}$ & approx. $4^{b}$ \\
\hline & & , $\mu$ moles & pmoles & $\mu$ moles & pmoles \\
\hline
\end{tabular}

\footnotetext{
a Molar concentrations of isoproterenol and ACTH-(1-24) that produce minimal (A) half-maximal (B), and maximal (C) stimulation of lipolysis and peak accumulation of cyclic AMP

b Maximal lipolysis expressed in $\mu$ moles glycerol release $/ 100 \mathrm{mg} / \mathrm{hr}$. Peak accumulation of cyclic AMP at time $7 \mathrm{~min}$ in pmoles $/ 100 \mathrm{mg}$. In both cases, basal values were subtracted
}

\section{Discussion}

Our work was performed with fragments of epididymal adipose tissue rather than isolated adipocytes. Genetically obese mice have enlarged adipocytes in various fat depots $[15,22]$. Chang et al. [23] have recently reported their inability to isolate these adipocytes from ob/ob mice: the collagenase treatment destroyed many cells and yielded free liposomes. According to Abraham and Beloff-Chain [24], the isolation procedure is particularly detrimental to large cells. The point is that basal lipolysis $[15,16]$ and the response to different lipolytic agents such as norepinephrine, ACTH, theophylline, dibutyryl-cyclic AMP and glucagon [16, 25, 26] are correlated with the size of the adipocytes. Thus, it appears that data obtained with isolated fat cells from obese animals are at best dubious and that the use of tissue fragments is well warranted.

Basal lipolysis has been reported to be higher $[15,16]$, equal [27], or lower [8] in obese tissue than in lean adipose tissue. This confusion is partly based on the mode of expression utilized. When data are expressed in terms of cellularity (i.e. per cell) rather than tissue weight (i.e. per $100 \mathrm{mg}$ wet weight), the values reported for young adult ob/ob adipose tissue necessarily increase 5 to 7 times, since the number of adipocytes is 5 to 7 times lower, on the same tissue weight basis, in the adipose tissue of obese mice than that of lean controls $[15,16,22]$. This, however, is not the only basis for discrepancy. Indeed, even when related to a wet weight basis, rather than a single fat cell, the basal lipolysis has been found to be greater in isolated ob/ob cells [15], and normal in $o b / o b$ tissue fragments $[14,27]$. By contrast, in our experiments glycerol release in 3 month old obese mice was three times lower than in lean animals of the same age (Figs. 3B and 5B).

In adipose tissue fragments from obese mice, both the sensitivity [15] and capacity $[8,14,28]$ of the lipolytic process were reported to be reduced in the presence of adrenaline, whereas a higher response to noradrenaline and ACTH was observed [16] in isolated fat cells from obese mice. Our own complete dose-response curves with isoproterenol and ACTH-(1-24) allow another interpretation. They indicate that the lipolytic capacity (maximal release of glycerol) was three times lower in obese mice than in lean controls, on the same adipose tissue wet weight basis (Figs. 3B and 5B). However, the sensitivity of both tissues for isoproterenol was of the same order of magnitude, as judged by concentrations needed for half-maximal lipolysis $\left(10^{-6} \mathrm{~mol} / \mathrm{l}\right.$ versus $5.10^{-6} \mathrm{~mol} / \mathrm{l}$ : Fig. $3 \mathrm{~B}$ and Table 2). A similar value $\left(7.10^{-7} \mathrm{~mol} / \mathrm{l}\right)$ has been obtained with rat adipose tissue [29]. The sensitivity of the adipose tissue of obese and normal mice towards ACTH was high in both cases since the same concentrations $\left(3.10^{-8} \mathrm{~mol} / \mathrm{l}\right)$ was sufficient to evoke half-maximal release of glycerol (Fig. 5 B). This may be due in part to the preincubation period which allows the elimination of ACTH inactivating factors from adipose tissue fragments [30]. At any rate, Schwabe and Ebert [31] found the same sensitivity to ACTH in isolated fat cells of rats.

Lavine et al. [32] found no difference in cyclic 
AMP levels in adipose tissue of normal and obese mice, when results were expressed on a DNA basis. Our data, which refer to the wet tissue weight, show that basal cyclic AMP levels were 2.5 times lower in obese animals than in normal mice (Table 1). Isoproterenol was able to increase this level remarkably in normal mice and the time course of stimulation (Fig. 1) resembled that observed in rat adipocytes [33]. After a peak value at 7-10 minutes, a sharp decrease followed. This decrease cannot be ascribed to the release of cyclic AMP in the medium, since this amount never exceeded $20 \%$ of the tissue content (data not shown). Several authors attribute this fall to the release of a hormone antagonist during the incubation [33-36]. We were unable to substantiate the release of such an inhibitor in the medium, since the time course of cyclic AMP levels in fresh adipose tissue fragments, from both types of mice, was not modified in the presence of an incubation medium which was previously utilized for isoproterenol-stimulated adipose tissue fragments from obese or lean mice (unpublished data). Therefore, we feel that a more satisfactory explanation for the secondary fall of cyclic AMP could be a desensitization of adenylate cyclase to norepinephrine [37] by an unknown hormone antagonist which remains intracellular.

The time course of cyclic AMP accumulation in adipose tissue from obese mice had a similar pattern, except that the peak levels reached were about 10 times lower. A similar impairment in cyclic AMP accumulation could be observed in 4 week old obese mice. However, we are unable to assess whether this defect preceded or followed the enlargement of fat cells since at 14 days of age ob/ob animals already have larger adipocytes [38]. In 3 month old mice, this difference had practically no bearing on the apparent sensitivity to isoproterenol. A 3 to $5 \times$ $10^{-7} \mathrm{~mol} / 1$ concentration gave a half-maximal burst of cyclic AMP accumulation in both types of mice (Fig. $3 \mathrm{~A}$ ). When compared with lipolytic activity, it is clear that a very low initial burst of cyclic AMP was all that was required to sustain a significant breakdown of triglycerides. This is confirmed with the ACTH-(1-24) data (vide infra).

ACTH binds to a plasma membrane receptor which is different from that of isoproterenol [39]. In lean mice, the concentrations of ACTH-(1-24) needed for minimal and half-maximal stimulation of cyclic AMP accumulation (Fig. 5A) were, respectively, 333 times and 10 times that needed to obtain lipolytic actions (Fig. 5B) of comparable amplitude (Table 2). This was even more striking in obese mice, where ACTH-(1-24) stimulated lipolysis without any increase in the tissue level of cyclic AMP. Such a dissociation suggests that the increase in cyclic AMP required for activating triglyceride lipase may be small and that the dramatic increase observed after hormonal activation of adenylate cyclase in normal adipose tissue is physiologically unnecessary. This is in line with the fact that theophylline, at a concentration $\left(10^{-3} \mathrm{~mol} / \mathrm{l}\right)$ sustaining maxi mal lipolytic response (data not shown), produced only a 3-4 fold increase in cyclic AMP levels (Table 1). In addition, another mediator of ACTH action might contribute to lipolysis in the absence of a detectable accumulation of cyclic AMP. Schwabe and Ebert [31] have already speculated about a dual control of lipolysis by ACTH, one involving cyclic AMP, the other one $\mathrm{Ca}^{2+}$. It would be of interest to study this problem further, even more so because hyperinsulinaemia in ob/ob mice might be a factor capable of altering $\mathrm{Ca}^{2+}$ pools [40].

Glucagon, VIP and secretin exert lipolytic effects on rat adipose tissue $[39,41,42]$. Our attempt to demonstrate the effect of glucagon and the two intestinal peptides was unsuccessful on mouse adipose tissue. The three hormones were ineffective on lipolysis and cyclic AMP accumulation in both lean and obese mice. We also obtained negative results with Swiss albino mice of the $\mathrm{Ha} / \mathrm{ICR}$ strain (data not shown). Thus, there appear to be no receptors for this class of hormones in mice.

Our data might be explained by a diminished number of hormone receptors. However, it seems difficult to attribute to a single gene mutation a defect concerning $\beta$-adrenergic and ACTH receptors simultaneously. Thus, it is likely that the coupling mechanism of hormone receptors to the catalytic subunit of the adenylate cyclase system and/or the catalytic subunit itself, are defective. This hypothesis $[43,44]$ will be further documented (in preparation). At any rate, the reduced hormone-stimulated lipolysis observed, in vitro, in obese-hyperglycaemic mice might suggest that in vivo, also, an impairment of lipolysis contributes to obesity, together with high local lipogenesis and a large influx of fatty acids of hepatic and dietary origin [45-47].

Acknowledgements Thıs work was supported by Grant 20,403 from the Fonds de la Recherche Scientifique Médicale (Belgium). J.P Dehaye is a Stagiaire de Recherches of the Fonds National de la Recherche Scientifique (Belgium). We are indebted to Dr. V. Mutt (GIH Research Unit, Karolinska Institutet, Stockholm, Sweden) for highly purified natural porcine VIP and porcıne secretin, Eli Lilly \& Co (Indianapolıs, U.S.A.) for pure crystalline porcine glucagon, and Dr. A. Daubresse (Ciba-Geigy, Brussels, Belgium) for ACTH (synthetic corticotrophin-(1-24) tetracosapeptide). We wish to thank Mr. K. Feuer and Mrs. J. Ballinckx for editing the manuscript 


\section{References}

1. Sutherland, E.W., Øye, I., Butcher, R.W.: The action of epinephrine and the role of the adenyl cyclase system in hormone action. Recent Prog. Horm. Res. 21, 623-646 (1965)

2. Robison, G. A., Butcher, R.W., Sutherland, E.W.: Cyclic AMP, p. 380. New York: Academic Press 1971

3. Steinberg, D., Huttunen, J.K.: The role of cyclic AMP in activation of hormone-sensitive lipase of adipose tissue. In: Advances in cyclic nucleotide research, Vol. 1, p. 47-62. New York: Raven Press 1972

4. Burns, T. W., Langley, P.E., Robison, G. A.: Studies on the role of cyclic AMP in human lipolysis. In: Advances in cyclic nucleotide research, Vol. 1, p. 63-85. New York: Raven Press 1972

5. Siddle, K., Hales, C.N.: Hormonal control of adipose tissue lipolysis. Proc. Nutr. Soc. 34, 233-239 (1975)

6. Lovell-Smith, C.J., Sneyd, J.G.T.: Lipolysis and adenosine $3^{\prime}, 5^{\prime}$-cyclic monophosphate in adipose tissue of the New Zealand obese mouse. J. Endocrinol, 56, 1-11 (1973)

7. Winand, J., Furnelle, J., Georis, M., Christophe, J.: Participation du foie et du tissu adipeux épididymaire à l'obésité de la souris obèse-Néo-Zélandaise (NZO) âgée d'un an. Bull. Soc. Chim. Biol. 50, 2069-2081 (1968)

8. Steinmetz, J., Lowry, L., Yen, T.T.T.: An analysis of the lipolysis in vitro of obese-hyperglycaemic and diabetic mice. Diabetologia 5, 373-378 (1969)

9. Yen, T. T. T., Steinmetz, J., Wolff, G. L.: Lipolysis in genetically obese and diabetes-prone mice. Horm. Metab. Res. 2, 200-203 (1970)

10. Shah, P.P., English, P.O., Bunyan, J.: Lipolysis in the adipose tissue of mice made obese with goldthioglucose. Biochim. Biophys. Acta 270, 86-91 (1972)

11. Armstrong, K.J., Stouffer, J.E., Van Inwegem, R.G., Thompson, W. J., Robison, G. A.: Effects of thyroid hormone deficiency on cyclic adenosine $3^{\prime}: 5^{\prime}$-monophosphate and control of lipolysis in fat cells. J. Biol. Chem. 249, 4226 -4231 (1974)

12. Knittle, J., Ginsberg-Fellner, F.: Adipose tissue cellularity and epinephrine stimulated lipolysis in obese and non obese children. Clin. Res. 17, 387 (1969)

13. Freychet, P., Laudat, M. H., Laudat, P., Rosselin, G., Kahn, C. R., Gorden, P., Roth, J.: Impairment of insulin binding to the fat cell plasma membrane in the obese hyperglycemic mouse. FEBS Lett. 25, 339--342 (1972)

14. Abraham, R. R., Dade, E., Elliott, J., Hems, D. A.: Hormonal control of intermediary metabolism in obese-hyperglycemic mice. II. Levels of plasma free fatty acids and immunoreactive insulin and liver glycogen. Diabetes 20 , 535-541 (1971)

15. Otto, W., Taylor, T. G., York, D. A.: Glycerol release in vitro from adipose tissue of obese (ob/ob) mice treated with thyroid hormones. J. Endocrinol. 71, 143-155 (1976)

16. Herberg, L., Gries, F.A., Hesse-Wortmann, Ch.: Effect of weight and cell size on hormone-induced lipolysis in New Zealand obese mice and American obese hyperglycemic mice. Diabetologia 6, 300-305 (1970)

17. Gilman, A. G.: A protein binding assay for adenosine $3^{\prime}, 5^{\prime}-$ cyclic monophosphate. Proc. Natl. Acad. Sci USA 67, 305312 (1970)

18. Arner, P., Östman, J.: Methodological aspects of protein binding assays for cycle AMP in human adipose tissue. Scand. J. Clin. Lab. Invest. 35, 691-697 (1975)

19. Vaughan, M.: The production and release of glycerol by adipose tissue incubated "in vitro". J. Biol. Chem. 237, 3354-3358 (1962)

20. Koschinsky, Th., Gries, F.A., Herberg, L . Regulation of glycerol kinase by insulin in isolated fat cells and liver of Bar Harbor obese mice. Diabetologia 7, 316-322 (1971)

21. Wieland, O.: Eine enzymatische Methode zur Bestimmung von Glycerin. Biochem. Z. 329, 313-319 (1957)

22. Johnson, P. R., Hirsch, J.: Cellularity of adipose depots in six strains of genetically obese mice. J. Lipid Res. 13, 2-11 (1972)

23. Chang, K. J., Huang, D., Cuatrecasas, P.: The defect in insulin receptors in obese-hyperglycemic mice: a probable accompaniment of more generalized alterations in membrane glycoproteins. Biochem. Biophys. Res. Commun. 64, 566-573 (1975)

24. Abraham, R. R., Beloff-Chain, A.: Hormonal control of intermediary metabolism in obese hyperglycemic mice. I. The sensitivity and response to insulin in adipose tissue and muscle in vitro. Diabetes 20, 522-534 (1971)

25. Livingston, J.N., Cuatrecasas, P., Lockwood, D. H.: Studies of glucagon resistance in large rat adipocytes: ${ }^{125}$ I-labeled glucagon binding and lipolytic capacity. J. Lipid. Res. 15, 26-32 (1974)

26. Hartman, A. D., Cohen, A. I., Richane, C. J., Hsu, T.: Lipolytic response and adenyl cyclase activity of rat adipocytes as related to cell size. J. Lipid Res. 12, 498-505 (1971)

27. Marshall, N.B., Engel, F.L.: The influence of epinephrine and fasting on adipose tissue content and release of free fatty acids on obese-hyperglycemic and lean mice. J. Lipid Res. 1, 339-342 (1960)

28. Leboeuf, B., Lochaya, S., Leboeuf, N., Wood, F. C. Jr., Mayer, J., Cahill, G. F. Jr.: Glucose metabolism and mobilization of fatty acids by adipose tissue from obese mice. Am. J. Physiol. 201, 19-22 (1961)

29. Aprille, J.R., Lefkowitz, R.J., Warshaw, J.B.: $\left[{ }^{3} \mathrm{H}\right]$ Norepinephrine binding and lipolysis by isolated fat cells. Biochim. Biophys. Acta 373, 502-513 (1974)

30. Müller, K., Maier, R.: Influence of the assay conditions on the lipolytic potency in vitro of different adrenocorticotrophins. Horm. Metab. Res. 8, 271-273 (1976)

31. Schwabe, U., Ebert, R.: Different effects of lipolytic hormones and phosphodiesterase inhibitors on cyclic $3^{\prime}, 5^{\prime}$-AMP levels in isolated fat cells. Naunyn-Schmiedebergs Arch. Pharmacol. 274, 287-298 (1972)

32. Lavine, R. L., Voyles, N., Perrino, P. V., Recant, L.: The effect of fasting on tissue cyclic AMP and plasma glucagon in the obese hyperglycemic mouse. Endocrinology 97, 615-620 (1975)

33. Ho, R.-J., Sutherland, E. W.: Formation and release of a hormone antagonist by rat adipocytes. J. Biol. Chem. 246, 6822-6827 (1971)

34. Illiano, G., Cuatrecasas, P.: Endogenous prostaglandins modulate lipolytic processes in adipose tissue. Nature 234, 72-75 (1971)

35. Fain, J. N., Shepherd, R. E.: Free fatty acids as feedback regulators of adenylate cyclase and cyclic $3^{*}: 5^{\prime}$-AMP accumulation in rat fat cells. J. Biol. Chem. 250, 6586-6592 (1975)

36. Schwabe, U., Ebert, R., Erbler, H.C.: Adenosine release from fat cells. effect on cyclic AMP levels and hormone actions. In: Advances in cyclic nucleotide research, Vol. 5, p 569-584. New York: Raven Press 1975

37. Mukherjee, C., Lefkowitz, R.J.: Desensitization of $\beta$-adrenergic receptors by $\beta$-adrenergic agonists in a cell-free system. resensitization by guanosine $5^{\prime}-(\beta, \gamma$-imino $)$ triphosphate and other purine nucleotides. Proc. Natl. Acad. Sci. USA 73, 1494-1498 (1976)

38 Joosten, H. F.P., Van der Kroon, P.H.W.: Enlargement of epididymal adipocytes in relation to hyperinsulinemia in obese hyperglycemic mice (ob/ob). Metabolism 23, 59-66 (1974) 
39. Birnbaumer, L., Rodbell, M.: Adenyl cyclase in fat cells. II. Hormone receptors. J. Biol. Chem. 244, 3477-3482 (1969)

40. McDonald, J.M., Bruns, D. E., Jarett, L.: Ability of insulin to increase calcium binding by adipocyte plasma membranes. Proc. Natl. Acad. Sci. USA 73, 1542-1546 (1976)

41. Rudman, D., Del Rio, A.: Lipolytic activity of synthetic porcine secretin. Endocrinology 85, 214-217 (1969)

42. Desbuquois, B., Laudat, M.-H., Laudat, Ph.: Vasoactive intestinal polypeptide and glucagon: Stimulation of adenylate cyclase activity via distinct receptors in liver and fat cell membranes. Biochem. Biophys. Res. Commun. 53, 1187-1194 (1973)

43. Laudat, M.-H., Pairault, J.: An impaired response of adenylate cyclase to stimulation by epinephrine-in adipocyte plasma membranes from genetically obese mice (ob/ob). Eur. J. Biochem. 56, 583-589 (1975)

44. Dehaye, J., Winand, J., Christophe, J.: Regulation of adenylate cyclase activity in the $25,000 \times \mathrm{g}$ sediment of adipose tissue from obese-hyperglycemic (ob/ob) mice from Bar Harbor. Arch. Int. Physiol. Biochim. 84, 154-156 (1976)

45. Christophe, J., Dehaye, J., Winand, J.: Utilization in vitro of $\left[\mathrm{U}^{14} \mathrm{C}\right]$ glucose, $\left[\mathrm{U}^{14} \mathrm{C}\right]$ fructose, $\mathrm{L}\left[\mathrm{U}-{ }^{14} \mathrm{C}\right]$ alanine and $\left[{ }^{3} \mathrm{H}\right]$ water in adipose-tissue fragments from Bar Harbor obese-hyperglycaemic mice. Biochem. Soc. Trans. 2, 12141215 (1974)

46. Winand, J., Furnelle, J., Wodon, C., Hebbelinck, M., Christophe, J.: 7-Day time study of lipid metabolism in normal and obese-hyperglycemic Bar Harbor mice. Qualitative and quantitative aspects. Biochimie 55, 63-73 (1973)

47. Lemonnier, D., Winand, J., Furnelle, J., Christophe, J.: Effects of a high-fat diet on obese-hyperglycaemic and nonobese Bar-Harbor mice. Diabetologia 7, 328-333 (1971)

Received: February 2, 1977, and in revised form: May 5, 1977

Dr. Jean Christophe

Laboratoire de Chimie biologique

et de la Nutrition Bâtiment A

Faculté de Médicine de l'Université libre de Bruxelles

Boulevard de Waterloo 115

B-1000 Brussels

Belgium 